\title{
Preparasi dan Karakterisasi Karbon Aktif Magnetik Nanopori
}

\author{
Aripin* \\ Jurusan Fisika, FMIPA, Universitas Haluoleo \\ Kampus Bumi Tridharma Anduonohu Kendari 93232
}

\begin{abstract}
Intisari
Bahan elektroda karbon aktif magnetik (KAM) dengan ukuran nanopori dari bahan baku kertas tisue sebagai sumber karbon dan $\mathrm{FeCl}_{2} .4 \mathrm{H}_{2} \mathrm{O}$ sebagai prekursor magnetik telah dikembangkan. Ukuran nanopori KAM diperlukan untuk mempercepat difusi elektrolit melewati elektroda, sehingga memaksimumkan kapasitansi spesifik EDLC. KAM dipirolisis pada temperatur $400^{\circ} \mathrm{C}, 500^{\circ} \mathrm{C}, 600^{\circ} \mathrm{C}$, dan $700^{\circ} \mathrm{C}$ selama 1 jam. Luas permukaan spesifik, volume pori total karbon dan diameter pori rata-rata KAM ditentukan dengan isotherm adsorpsi nitrogen menggunakan Surface Area Analyzer Nova-1000. Hasil menunjukkan bahwa luas permukaan spesifik dan diameter pori rata-rata karbon aktif magnetik berturut-turut adalah antara $700 \mathrm{~m}^{2} / \mathrm{g}$ sampai di atas $1200 \mathrm{~m}^{2} / \mathrm{g}$ dan antara $1 \mathrm{~nm}$ sampai di atas $15 \mathrm{~nm}$.
\end{abstract}

KATA KUNCI: karbon aktif magnetik (KAM), karbonasi, luas permukaan spesifik, diameter pori rata-rata

\section{PENDAHULUAN}

Karbon aktif dan arang (karbon berpori) secara teknis merupakan bahan penting dan telah digunakan sebagai bahan elektroda EDLC [1-3]. Elektroda karbon aktif memiliki luas permukaan spesifik besar sehingga cocok untuk proses adsorpsi dan deadsorpsi ion-ion elektrolit tanpa reaksi elektrokimia dan bahan ini adalah konduktif secara elektronik, yang memungkinkan siklus pengisian dan pengosongan muatan dilakukan secara lengkap dan cepat. Meskipun karbon aktif dan karbon berpori telah digunakan, tetapi belum memberikan unjuk kerja maksimal sebagai bahan elektroda EDLC. Hal ini dihubungkan terhadap masalah banyak EDLC yang tersedia sekarang menggunakan bahan elektroda karbon konvesionall yang hanya mengandung ukuran mikropori. Mikropori tidak mudah dibasahi elektrolit dan permukaan yang terlindung dalam mikropori tidak dimanfaatkan untuk menyimpan muatan. Selanjutnya, jika dalam situasi dimana mikropori dibasahi elektrolit, gerakan ion dalam pori kecil ini terlalu lambat. Kedua, resistansi kontak antara partikel serbuk karbon dan antara lapisan aktif dan plat pengumpul arus sangat besar, sehingga dapat menurunkan kapasitansi EDLC. Pengembangan elektroda karbon aktif magnetik (KAM) yang mempunyai ukuran pori yang cukup besar dan resistansi kontak rendah sangat diperlukan dan penting untuk mempercepat difusi elektrolit melewati elektroda, sehingga memaksimumkan kapasitansi spesifik EDLC. Tujuan penelitian ini adalah mempersiapkan dan menentukan struktur permukaan karbon aktif magnetik nanopori.

${ }^{*}$ E-MAIL: aripin01@yahoo.com

\section{DASAR TEORI}

\section{A. Metode BET}

Pengukuran isoterm adsorpsi mempunyai beberapa penggunaan terutama untuk menentukan luas permukaan adsorben. Luas permukaan padatan meliputi luas permukaan internal (mikroskopik) dan luas permukaan eksternal (makroskopik). Pada sistem adsorpsi gas-padat biasanya dinyatakan oleh isoterm adsorpsi dengan tipe-tipe antara lain; tipe Langmuir, Freundlich, BET, modifikasi tipe BET dan modifikasi tipe Freundlich.

Pada pengukuran luas permukaan zat padat digunakan isoterm multilapisan. Isoterm yang umum digunakan pada adsorpsi multilapisan diturunkan oleh Stepher Brunaeur, Paul Emmett dan Edward Teller yang disebut isotherm BET [4]. Metoda ini menganggap bahwa molekul padatan yang paling atas berada dalam kesetimbangan dinamis. Ini berarti jika permukaan hanya dilapisi oleh satu molekul saja, maka molekulmolekul gas ini berada dalam kesetimbangan dengan fase uap padatan. Jika terdapat dua atau lebih lapisan, maka lapisan teratas yang berada pada kesetimbangan dengan fase uap padatan. Bentuk isoterm tergantung pada macam gas adsorbat, sifat adsorben, struktur pori. Gejala yang diamati pada adsorpsi isoterm berupa adsorpsi lapisan molekul tunggal, adsorpsi lapisan molekul ganda dan kondensasi dalam kapiler.

Penurunan persamaan adsorpsi BET didasarkan pada teori kinetik gas (teori Langmuir) untuk n lapisan/multi lapisan. Teori ini mengasumsikan bahwa :

1. Laju adsorbsi sama dengan laju desorbsi

2. Tumbukan antar molekul diabaikan

3. Tumbukan antara molekul dengan permukaan (adsorbat-adsorben) bersifat elastis

4. Permukaan adsorben bersifat homogen. 
Persamaan BET dapat ditulis sebagai berikut :

$$
\frac{1}{W\left(\frac{p_{\circ}}{p}-1\right)}=\frac{1}{W_{m} c}+\frac{c-1}{W_{m} c} \frac{p}{p_{\circ}}
$$

dengan $\mathrm{p} / \mathrm{p}_{\circ}=$ tekanan relatif, $\mathrm{W}=$ berat gas yang diserap (adsorben) pada tekanan relatif $\mathrm{p} / \mathrm{p}_{\circ}, \mathrm{W}_{m}=$ berat gas nitrogen yang membentuk lapisan monolayer pada permukaan zat padat, $\mathrm{c}=$ tetapan $/ \mathrm{konstanta} \mathrm{BET}$.

\section{B. Jari-Jari Pori}

Pengamatan gejala kondensasi kapilaritas dalam proses adsorpsi akan membantu dalam penentuan-jari-jari dan volume pori. Kondensasi kapiler terjadi saat tekanan diturunkan dan molekul gas adsorben tidak segera lepas dari dalam pori sehingga tidak seperti pada permukaan yang datar. Berdasarkan asumsi tersebut dan penerapan persamaan Gibss-Duhem pada saat kesetimbangan (temperatur konstan), maka radius pori dapat diketahui dengan mengetahui besarnya radius meniskus yang terbentuk. Persamaan mengenai jari-jari meniskus tersebut diturunkan oleh Kelvin sebagai berikut [4] :

$$
r_{m}=-\frac{2_{\gamma} V_{L}}{R T \ln \left(p / p_{\circ}\right)}
$$

dengan $\mathbf{r}_{m}$ = radius meniskus dari adsorben yang terkondensasi dalam pori $(\stackrel{\AA}{A}), \mathrm{V}_{L}=$ volume molar adsorbat dalam keadaan cair $\left(34.68 \mathrm{~cm}^{3} / \mathrm{mol}\right), \gamma=$ tegangan permukaan kondensat $\left(8.8810^{-3} \mathrm{~N} / \mathrm{m}\right), \mathrm{R}=$ tetapan gas $(8,314 \mathrm{~J} / \mathrm{mol} \mathrm{K}=$ $0,082 \mathrm{~atm} .1 \mathrm{tr} / \mathrm{mol} \mathrm{K}), \mathrm{T}=$ temperatur absolut $(\mathrm{K})$.

Ukuran pori digolongkan menjadi tiga kelompok yaitu makropori mempunyai diameter rata-rata lebih dari $50 \mathrm{~nm}$, mesopori dengan diameter 2 - $50 \mathrm{~nm}$ dan mikropori mempunyai diameter rata-rata kurang dari $2 \mathrm{~nm}$. Selanjutnya mikropori dibagi menjadi dua kelompok yaitu supermikropori mempunyai diameter rata-rata $0,7-2,0 \mathrm{~nm}$ dan ultramikropori mempunyai diameter kurang dari $0,7 \mathrm{~nm}$.

\section{METODOLOGI PENELITIAN}

Serbuk karbon aktif magnetik disintesis menggunakan kertas tissue sebagai sumber karbon dan $\mathrm{FeCl}_{2} \cdot 4 \mathrm{H}_{2} \mathrm{O}$ sebagai prekursor magnetik. Serbuk disintesis menurut prosedur yang dikerjakan sebelumnya [5]. Kertas tissue dicelupkan ke dalam larutan dari campuran $10 \mathrm{~g} \mathrm{FeCl}_{2} \cdot 4 \mathrm{H}_{2} \mathrm{O}$ dan $30 \mathrm{ml}$ aquades sampai jenuh. Kertas tissue yang telah dicelupkan dikeringkan di udara luar. Lima jenis kertas tissue dicelupkan ke dalam lautan (KAM) kemudian dipirolis pada $400^{\circ} \mathrm{C}, 500^{\circ} \mathrm{C}$, $600^{\circ} \mathrm{C}$, dan $700^{\circ} \mathrm{C}$ selama 1 jam berturut-turut ditandai dengan KAM1, KAM2, KAM3, dan KAM4. Kemudian produk pirolisis didinginkan dan dicuci untuk menghilangkan agenagen aktivasi. Selanjutnya KAM berpori dikeringkan selama 1 jam pada $115^{\circ} \mathrm{C}$ dan kemudian disimpan dalam desikator.

Luas permukaan dan porositas KAM dikarakterisasi menggunakan eksperimen adsorpsi gas volumetrik. Eksperimen

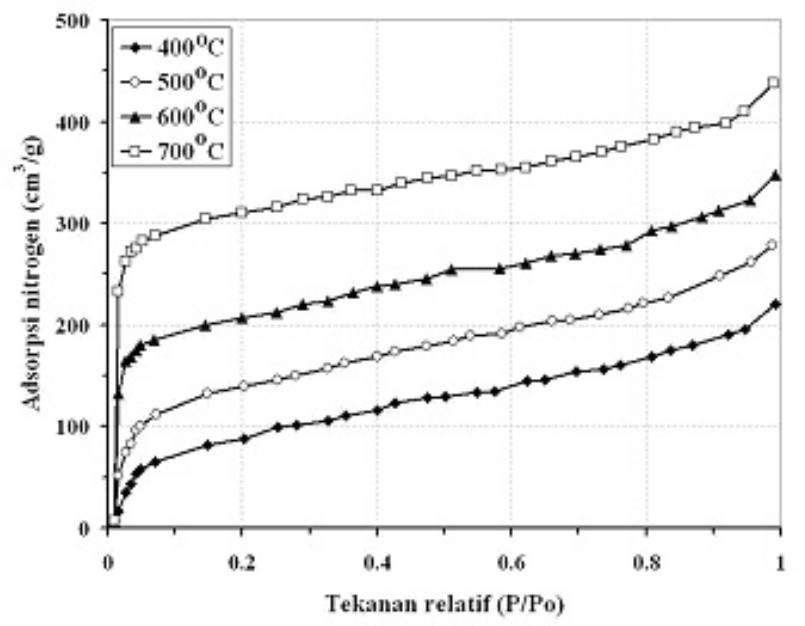

Gambar 1: Isotherm adsorpsi nitrogen untuk KM pada variasi temperatur pirolisis.

ini ditampilkan menggunakan Surface Area Analyzer Nova1000 di BATAN Yogyakarta. Dalam eksperimen adsorpsi, N2 sebagai adsorbat dan temperatur pada $77 \mathrm{~K}$ dikontrol menggunakan dengan kamar nitrogen cair. Teori Brunauer, Emmet dan Teller (BET) digunakan untuk menghitung luas permukaan KAM. Luas permukaan (S) dihitung dari plot BET dalam rentang tekanan relatif 0,01 sampai 0,15 . Volume $(\mathrm{V})$ pori lebih kecil dari $30 \mathrm{~nm}$ dalam diameter ditentukan dari perhitungan nitrogen yang terserap pada tekanan relatif 0,931 . Diameter pori rata-rata (D) dihitung dari $\mathrm{D}=4 \mathrm{~V} / \mathrm{S}$, dan sistem pori dianggap sebagai kapiler selinder.

\section{HASIL DAN DISKUSI}

Gambar 1 menunjukkan isotherm adsorpsi nitrogen KM untuk variasi temperatur pirolisis. Ordinat adalah gas yang teradsorpsi per gram oleh KM dan absis adalah tekanan relatif P/Po, adsorptif dalam hal ini adalah $\mathrm{N}_{2}$, dimana Po adalah tekanan uap jenuh $\mathrm{N} 2$ pada temperatur eksperimen. Jenis isotherm KAM untuk temperatur pirolisis pada $400^{\circ} \mathrm{C}$, $500^{\circ} \mathrm{C}, 600^{\circ} \mathrm{C}$, dan $700^{\circ} \mathrm{C}$ merupakan karakteristik sampel tipe kombinasi mikropori dan messopori [6]. Isotherm jenis ini adalah jenis zat padat mikropori dimana hanya terjadi pada adsorpsi lapisan tunggal. Pengisian mikropori terjadi pada tekanan rendah; $0,1 \mathrm{p} / \mathrm{p}_{\circ}$, dan pengisian makropori terjadi pada tekanan $0,1 \mathrm{p} / \mathrm{p}_{\circ}$ sampai $0,93 \mathrm{p} / \mathrm{p}_{\circ}$. Gambar 2 menunjukkan luas permukaan spesifik untuk KAM pada berbagai temperatur pirolisis. Luas permukaan spesifik KAM diperoleh dengan analisis BET. Besarnya nilai luas permukaan spesifik untuk KAM adalah berkisar antara $700 \mathrm{~m}^{2} / \mathrm{g}$ dan di atas $1200 \mathrm{~m}^{2} / \mathrm{g}$. Luas permukaan spesifik bertambah, jika temperatur pirolisis dinaikan dari $400^{\circ} \mathrm{C}$ sampai $700^{\circ} \mathrm{C}$. Perilaku ini dihubungkan terhadap polaritas permukaan yaitu jumlah gugus-gugus fungsional yang berhubungan dengan gugus karboksil pada permukaan bahan KAM berkurang jika temper- 


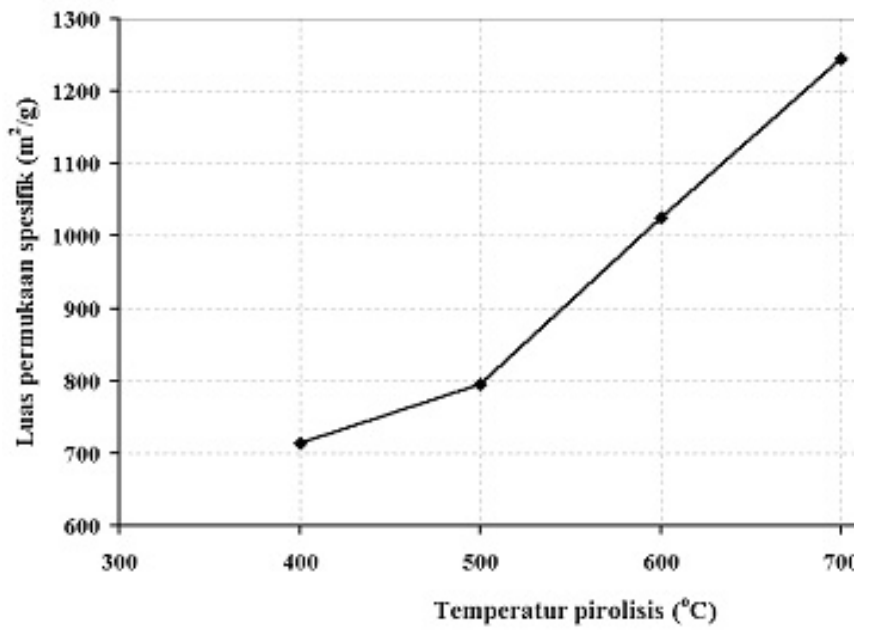

Gambar 2: Luas permukaan spesifik KAM untuk variasi temperatur pirolisis

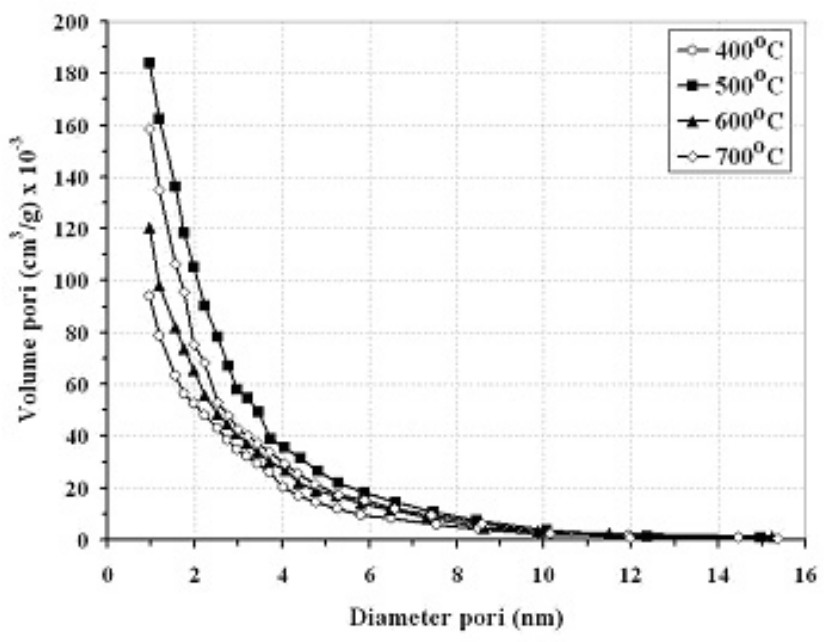

Gambar 3: Distribusi ukuran pori KAM untuk variasi temperatur pirolisis

atur pirolisis dinaikan [5]. Polaritas permukaan bahan KAM menurun, jika temperatur pirolisis dinaikan. Gambar 3 menunjukkan distribusi ukuran pori KAM untuk variasi temperatur pirolisis. Pori dalam KAM tersebar dalam bentuk dan ukuran yang sangat lebar. Berdasarkan IUPAC, ukuran diame- ter pori untuk KAM dapat digolongkan sebagai mikropori dan messopori (nanopori) dengan diameter pori berkisar berkisar antara $1 \mathrm{~nm}$ dan di atas $15 \mathrm{~nm}$.

Berdasarkan distribusi ukuran pori dari KAM yang diperoleh dari hasil penelitian ini yaitu kombinasi mikropori dan messopori, maka jika bahan ini digunakan sebagai bahan elektroda EDLC memungkinkan dapat meningkatkan kapasitansi EDLC. Ukuran pori kombinasi mikropori dan messopori sangat cocok untuk pemakaian elektrolit encer $\mathrm{H} 2 \mathrm{SO} 4$ dan elektrolit $\mathrm{LiClO}_{4}$. Ion $\mathrm{H}^{+}$dari elektrolit $\mathrm{H}_{2} \mathrm{SO}_{4}$ mempunyai ukuran sangat kecil sehingga dapat dengan mudah mengambil bagian dalam proses penyisipan berulang-ulang ke dalam pori KAM. Ion $\mathrm{SO}^{4-}$ dari $6\left(\mathrm{SO}^{2-} .\left(\mathrm{H}_{2} \mathrm{O}\right)_{6}\right)$ dan $12\left(\mathrm{SO}^{2-} .\left(\mathrm{H}_{2} \mathrm{O}\right)_{1} 2\right)$ berturut-turut mempunyai diameter ratarata sekitar 0,409 nm dan 0,533 nm [5]. Sedangkan elektrolit $\mathrm{LiClO} 4$ terpisah menjadi ion $\mathrm{Li}+$ dan $\mathrm{ClO} 4-$ dengan diameter rata-rata masing-masing sekitar $1,19 \mathrm{~nm}$ dan $0,49 \mathrm{~nm}$ [2]. Jika distribusi ukuran pori KAM hanya mikropori, maka ion-ion akan berdifusi lambat memasuki pori. Pori dengan ukuran mikropori hanya berhubungan terhadap satu atau dua diameter ion $\mathrm{SO}^{4-}$, sehingga hanya menyediakan satu atau dua ion $\mathrm{SO}^{4-}$ untuk menjangkau permukaan pori KAM. Jika distribusi ukuran pori KAM merupakan kombinasi mikropori dan mesopori, ion-ion elektrolit memasuki messopori akan berlipat-lipat, sehingga elektroda akan mudah dibasahi elektrolit dan permukaan yang terlindung dalam mikropori akan dimanfaatkan untuk menyimpan muatan. Selanjutnya, jika dalam situasi dimana messopori dibasahi elektrolit, gerakan ion dalam pori kecil ini akan cepat.

\section{SIMPULAN}

Karbon yang mengandung magnetik (KM) telah dibuat dengan menggunakan kertas tissue sebagai sumber karbon, $\mathrm{FeCl}_{2} .4 \mathrm{H}_{2} \mathrm{O}$ sebagai prekursor magnetik dan temperatur pirolisis. Metode ini telah berhasil mengembangkan luas permukaan spesifik yang besar dan kombinasi struktur mikropori dan mesopori (nanopori). Luas permukaan spesifik KAM berkisar antara $700 \mathrm{~m} 2 / \mathrm{g}$ dan di atas $1200 \mathrm{~m}^{2} / \mathrm{g}$. Ukuran diameter pori berkisar antara $1 \mathrm{~nm}$ dan di atas $15 \mathrm{~nm}$. Luas permukaan spesifik bertambah, jika temperatur pirolis dinaikan yang dihubungkan terhadap pengurangan jumlah gugus-gugus fungsional dari gugus karboksil pada permukaan bahan KAM. Bahan KAM dengan karakteristik ukuran mesopori sangat bermanfaat untuk aplikasi praktis dalam EDLC.
[1] Endo, M., Takeda, T., Kim, Y.J., Khoshiba, K., Ishii, K., Carbon Science, 1, 117-128.C (2001).

[2] Lazano-Castello, D., Cazorla-Amoros, D., Linares-Salano, A., Shirashi, S., Kurihara, H., Oya, A., Carbon Science, 41, 17651775 (2003).

[3] Chemiola, J., Yushin, G., Dash, R.K., Hoffman, E.N., Fisher, J.E., Barsoum, M.W., and Gogotsi, Y., J. Electrochem. and Solidstate Letter, 8, A357 - A360 (2005).
[4] Gregg, S.J., and Sing, K.S.W., Adsorption, Surface Area and Porosity, Academic Press Inc. London (1982).

[5] Aripin, J.of Solid State Science and Technology Letters, 13, 1922 (2006).

[6] Sing, K.S.W., Everett, D.H., Haul, R.A.W., Moscou, L., Pierotti, R.A., Rouquerol, J., Pure Appl Chem., 57, 603-619 (1985). 